\title{
Active particiation of university students in defending rights of children
}

\section{Çocukların haklarını savunmada üniversite öğrencilerinin aktif katılımı}

Selda Bülbül, Ayşegül Alpcan

Kırıkkale University, Faculty of Medicine, Department of Pediatrics, Kırıkkale, Turkey

$\begin{array}{lll}\text { Received: 14.03.2018 Accepted: 15.05.2018 Doi:10.21601/ortadogutipdergisi.405780 } & \text { Act }\end{array}$

\begin{abstract}
Convention on the Rights of the Child (CRC) is the most powerful tool availableto improve thewell-being of children. Civil, economic, social, cultural, and political rights of children all of which covered survival, development, protection, and participation were included in the convention. Though, participation has been the most radical element of the $\mathrm{CRC}$, still children are not regarded as autonomous individuals fully entitled to enjoy their rights. Therefore, proffesionals started to give more interest on participation rights of children. In this article we represented an example of a structural component of participation approaches in a Turkish University which aimed including the youth into social work in the field of childens' right. The main goal of the given project was to create awareness on Children's rights among university students and to create adults globally advocating for human rights and the rights of children.
\end{abstract}

Keywords: Child, Convention on the Rights of Child, well-being of children

\section{Öz}

Çocuk Haklarına Dair Sözleşme, çocukların refah durumunu iyileştirmek için mevcut en güçlü araçtır. Sözleşmeye çocukların hayatta kalma, gelişme, koruma ve katılımı kapsayan sivil, ekonomik, sosyal, kültürel ve politik hakları dahil edildi. Her ne kadar katılım çocuk hakları sözleşmesinin en radikal unsuru olsa da, hala çocukların haklarından yararlanma hakları olan özerk bireyler olarak görülmemektedir. Bu nedenle profesyoneller, çocukların katılım hakları konusunda daha fazla ilgi duymaya başladı. Bu yazıda, bir Türk Üniversitesinde gençlerin sosyal çalışmalara katılmalarını sağlamayı amaçlayan yaklaşımların yapısal bir bileşenini örnek olarak sunduk. Verilen projenin temel amacı, üniversite öğrencilerinin Çocuk hakları konusunda farkındalığını oluşturmak ve tüm dünyada insan haklarını ve çocukların haklarını savunan yetişkinler oluşturmaktı.

Anahtar Kelimeler: Çocuk, Çocuk Hakları Sözleşmesi, çocuk esenliği 


\section{Introduction}

At present, the social, economic, and political environments that children live in and develop are being recognized as the most important actual determinants of child health. To improve the well-being of children, ensuring children's rights and use of the UN Convention on the Rights of the Child (CRC) are the most efficient tools available [1,2]. The convention included civil, economic, social, cultural, and political rights of children all of which covered survival, development, protection, and participation. It builds the eventual responsibility of all governments, institutions, and the family to maintain that these rights are respected and all their actions dealing with children are performed in children's best interests [3].

Nowadays participation is a popular item and it has been postulated by some authors that, health promotion programmes should aim to improve working relationships with young people [4]. It was stated by Woll in 2001 that, children's participation in organizations has been the most radical element of the CRC [5]. The evidence suggests that good practice includes a listening culture among staff, clarity, flexibility, adequate resources, skills development and training for staff and participating children and young people in recieving feedback and evaluation. More evidence about children's views and their experience of participation in public decision-making is required. This can be micro level policy (ruling and household regulations in residential settings e.g) or at the level of the organisation (through a board of youngsters) or by extension in society. In a participative care, a communicative process which is the relation between professional worker and the child/youngster requires specific skills. For care takers this is a very difficult job, it challenges them to find a way of using their expertise and still define the relationship as equal. Furthermore professional care takers are schooled and trained towards a protective attitude and in 'knowing what's best' for the youngsters. For those who work with children in the health service and/or in justice system, there is no escaping the fact that the responsibility of ensuring the rights of children as established in the convention rests with us $[2,4,6]$.

\section{Current Situation in Turkey}

Concerted right efforts for the children will help developing safer communities and nations across the globe. Therefore, Turkey has been one of the 191 States parties to the Convention on the Rights and was accepted to regulate the con- vention in $1990[7,8]$. However, still a generious progress is needed in the four main issues of Chidren's Rights. This is where parents, communities and government should work for and support human rights for children to achieve better society of the future. On a parental or teacher's and even on children's scale the general knowledge on children's right is limited [9]. There are several ongoing projects in Turkey on participation rights of children. One of the very successfull applications was done by Ministry of Education, which was to establish children's parliaments in the schools [10].

Turkey has been a country cognizant of child care and protection. The affection and mercy engrained in Turkish culture has made children's rights the focal point of family behaviour. 23rd April, the day of the inauguration of the Turkish Grand National Assembly in 1920, as Children's Day was an outcome of that understanding [11]. However, parental authority is very strong in Turkish society. Still children are not regarded as autonomous individuals fully entitled to enjoy their rights. Therefore, proffesionals started to give more interest on participation rights of children in Turkey. In this article we represented an example of a structural component of participation approaches in a Turkish University which aimed including the youth into social work in the field of childens' right.

Active Participation of University Students; the Project of Kırıkkale University.

So far importance on activating children in participation has been mainly given on primary or secondary school levels in Turkey, and there are not many ongoing projects targeting university students. The main goal of the given project was to create awareness on Children's rights and to ensure the active participation of the university students in defending the rights of children. Target population of our project was university students aged 17-24 years. Therefore, the major aim was to create adults globally advocating for human rights and the rights of children.

\section{Objectives of the Project were;}

- To be the protectors of survival and development rights of children

- Make a contribution in maintaining a University youth who are aware of their own rights and who constitute a youth behaviour, culture and live in accordence with these rights

- To raise advocates of "children's rights" in all areas

- To share our knowledge and to render conscious on this 
topic among university students, primary and secondary school students, parents, teachers and among all who deals with children in Kirikkale province

- To raise public awareness on the "Convention on the rights of the children"

- To start activities against every kind of child discrimination

\section{Strategies of the Project}

- Create a training and education network in our university by maintaining the participation of university students

- To share our knowledge with public via conferences and activities (parties, interactive meetings, visits etc.) in our province

- To publish articles in local newspapers and to disperse brochures to widen this issue and to reach more people

- To mobilise all sectors (Governorship, municipality, Provincial safety(policeman) directory, Provincial Education Directory, Provincial Health Directory) and resources for the better implementation of children's rights

This project was established by the Kırıkkale Branch Office of UNICEF Turkish National Committee, Turkish National Pediatrics Society (ICC-TNPS) and International Children's center in 2003.

First activity of the Project team was the establishment of "Kırıkkale University, Children Friendly Club" (KUCFC) as a social group in the University. This would both allowed us to work as a team with the students and would make a contribution to help students and children to exprience themselves in a social group. This club is consisted of medical and Law school students to advocate child rights either in our university and our province or in other schools and in Turkey. At first it had 22 members (6 doctors from the department of pediatrics Medical School, Kırıkkale University, 7 students from the Medical school, Kırıkkale University and 9 students from the Faculty of Law, Kırıkkale University). As the years past, the number of the club members reached over 200 students.

The first seminar was held in the Kirkkale University campus in 13th November 2003. The main topics of this seminar were: a) Children's rights from yesterday to today, b) History of Convention on the Children's Rights in Turkey, c) Present stiuation in Turkey and judicial procedures that are related to children rights in Civil Law, Criminal Law, and in Social Services and Children Protection Law, and gaps in implementation of these laws. In the first five years club members presented seminers on children's rights in various secondary and high schools in Kırıkkale and Ankara. Moreover, to widen the project to other university students, the club attended to the student spring fests of Kirıkkale, Hacettepe and Bilkent Universities and sell the postcards and T-shirts of UNICEF on the desk of our club, while they were introducing the club and giving information about its activities. Delegates of the club attended to the national meetings of "Turkish Youth Council Enterprice" and National Pediatric Meetings to represent the club and to share expriences with other youth groups and authorities between 2003 and 2010 .

The Childrens' Rights Day "20th November " was celebrated in Kirıkkale every year with presentations to different governmental organizations, movie shows established by the Kırıkkale Police Directory, participating to people walks in the city center and attending to media programmes (TV and/or radio) to emphasize the importance of the day and the children's rights. In the past ten years, the club continued its activities, by clothing distribution to poor children, establishing libraries in village schools and preparing magazine/newspaper articles.

As a result the club was well known in the province and the members were invited to take part in conferences and/ or different activities carried out by different institutions in Kirıkkale province. We believe that the club had some contribution in creating a right based life for children of Kirikkale. As the consultant of the students, I still have contact with old members of the club. At present, they are working in different parts of Turkey as doctors or lawyers who became the pionners of children's right based applications in their province.

The clup continued with new university students untill then and changed its name to Kirikkale University Faculty of Medicine Small Steps Club (KUTKA) in 2013. With the changing needs of the province they prepared different projects for different need groups such as abused teenaged girls. In this context, the last project of the club was prepared with Kirıkkale Nursing And Social Rehabilitation Center (NSRC) in December 2013.

In Turkey, residential social service organizations, Nursing And Social Rehabilitation Centers (NSRC), have been established to provide the protection and safety of the girls who are victims of sexual abuse. While fulfilling their mission of providing accomodation and protection, NSRCs are also striving for the children they accommodate to be 
able to complete their physical, mental and emotional developments in a healthy manner.

The objectives of the project were stated as;

a. To support the employees of the institution,

b. To alleviate the traumas and/or the behavioral disorders resulting from the children's negative life experiences by acting as elder sisters/friends towards the girls in NSRC,

c. To assist with promoting the children's relations with family, and society in this process,

d. To help create career goals for the future and to reintegrate the children into society.

The KUTKA students were informed by the authorities of the institution about the interviewing techniques, communication skills with trauma-exposed children and how they should approach the children.

Within the framework of the project, a group of female students consisting of KUTKA members visited Kirikkale NSRC regularly and they communed with the girls.

There were 22 registered girls between 12-18 years of age in Kirikkale NSRC. The mean age of the children was 15.68 years, and 3 girls were attending to formal high schools and 16 children continued to study in the open education high school. Each student was paired with a child and paid attention to visit the same child every time.

During the project, medical students and female students met each other once a week. However, in some weeks due to short holidays and examinations of our students, all pairs of students and children could not come together and this caused a decline of confidence in girls.

The members of KUTKA stated that they received positive feedback after their interviews with the young, some girls were able to express themselves better, and school success of some girls were increased.

Lastly we have discussed the young students'perspectives on the project and their gains as given below:

1.) They have seen the lack of information on children and human rights at all stages of the education system in Turkey

2.) They expressed their experiences with professionals during the execution of the project. And mostly emphasised the actions of professionals that they defined as positive:

- explanations that include positive and negative information;
- searching for all opportunities for the youth; - respect and trust, shown to the youth by the professional; - endeavour at work and standing up for the youth;

3) They learned to feel comfortable in environments which mostly professionals take part in.

4) They all strongly emphasised that, they gained their strength for the future as when they will be independent and in the ideas of what they will achieve.

In the context of our project, it has been shown that, even though they were university students in Medical School and Faculty of Law, they were still poorly informed as regards their rights. Therefore, at every state even in universities youth and children need more information and a better explanation on their own rights.

The expanded social consciousness through individual expression, will help elevating the social standard of living and enrich the general quality of life. In conclusion, we believe that youth are very important sources to widen up this conscious. We believe that when students start to work on this topic during the university years, they will become more sensitive and responsible on children's rights as professionals than the counterparts in future.

\section{Declaration of Conflicting Interests}

The author declared no conflicts of interest with respect to the authorship and/or publication of this article.

\section{References}

1. Goldhagen J . Children's Rights and the United Nations Convention on the Rights of the Child. Pediatrics 2003 Sep; 112: 742-5.

2. Andersen CS, Dolva AS. Children's perspective on their right to participate in decision-making according to the United Nations Convention on the Rights of the Child article 12. Phys Occup Ther Pediatr 2015; 35; 218-30

3. Convention on the Rights of the Child. UN GA Res 44/25. Available at: http://www.unhchr.ch/html/menu3/b/k2crc.htm. (Accessed July 25,2006)

4. Moore L, Kirk S. A literature review of children's and young people's participation in decisions relating to health care. J Clin Nurs. 2010;19(15-16):2215-25. doi: 10.1111/j.1365-2702.2009.03161.x.

5. Woll L. Organizational responses to the Convention on the Rights of the Child: international lessons for child welfare organizations. Child Welfare 2001 Sep-Oct; 80: 668-79 
6. O'Hare BA, Devakumar D, Allen S. Using international human rights law to improve child health in low-income countries: a framework for healthcare professionals. BMC Int Health Hum Rights. 2016;16:11. (Erişim tarihi: 8.01.2018, https://www.ncbi.nlm.nih. gov/pmc/articles/PMC4815083/pdf/12914_2016_Article_83.pdf)

7. Making a difference for children Unicef Turkey Funding Guide http://www.unicef.org/turkey/ pdf/dn.pdf (Accessed 12.02.2016).

8. Genckaya O, ToLgan S, Schulz L, KaradagR. Sustainable Governance Indicators http:// www.sgi-network.org/docs/2015/country/SGI2015_Turkey.pdf (Accessed Date: 10.01.2016)

9. Analysis of the Situation of Children and Young People in Turkey 2012 http:// www.unicef.org.tr/files/bilgimerkezi/doc/sitan-finaleng-2012.pdf
10. http://mevzuat.meb.gov.tr/html/2564 0.html (Accessed Date: 08.03.2016)

11. Kirimlioglu N, Elcioglu O. Children's Health Rights in Turkey. Eubios J Asian Int Bioethics 2002; 12: 221-3.

Corresponding Author: Selda Bülbül, Kırıkkale University, Faculty of Medicine, Department of Pediatrics, Yahşihan, 71450, Kırıkkale, Turkey

E-mail: seldabulbul@gmail.com

Mobile: +90 5423125188 